\title{
Characterization of Fruit Morphological Parameters and Effect of Pre- Sowing Treatment in Phoebe Cooperiana: An Economically Important Wild Edible Fruit of Arunachal Pradesh
}

\author{
Narang Dolley $^{1}$, N. Lyngdoh ${ }^{1}$, M. Bishwapati Devi ${ }^{2}$ and B.N. Hazarika ${ }^{3}$ \\ ${ }^{1}$ Department of Tree Improvement, ${ }^{2}$ Department of Basic Sciences, ${ }^{3}$ Office of the Dean, \\ College of Horticulture and Forestry, Central Agricultural University, Pasighat, Arunachal \\ Pradesh-791102, India \\ *Corresponding author
}

Keywords

Tapir, Germination, Gibberlic acid, Adi

Article Info

Accepted:

20 March 2019

Available Online:

10 April 2019

\section{A B S T R A C T}

The experiment was conducted to characterize the fruit morphological parameters and to study the effect of different pre-sowing treatment on seeds of wild edible fruit tree Phoebe cooperiana U.N Kanjilal ex A. Das. of Arunachal Pradesh. Fruit and seed morphological parameters were based on 100 fruits collected from Lower Dibang district of Arunachal Pradesh. Eight pre-sowing treatments in three replications were given to the seeds before sowing at Department of Tree Improvement nursery, College of Horticulture and Forestry, Pasighat, Arunachal Pradesh. The average fruit weight for the 100 fruits was recorded to be $9.64 \pm 1.90 \mathrm{~g}$; fruit length $3.62 \pm 0.37 \mathrm{~cm}$; fruit diameter $2.42 \pm 0.59 \mathrm{~cm}$; seed weight 3.10 $\pm 0.70 \mathrm{~g}$; seed length $2.45 \pm 1.01 \mathrm{~cm}$; seed diameter $1.35 \pm 0.24 \mathrm{~cm}$; pulp weight $6.69 \pm$ $1.10 \mathrm{~g}$; pulp thickness $1.07 \pm 0.10 \mathrm{~cm}$ and pulp-fruit ratio $0.64 \pm 0.21$. Significant differences in germination were observed across the treatments. The study revealed that treatment $\mathrm{T}_{5}$ (soaking in $0.05 \%$ gibberellic acid for $12 \mathrm{hrs}$ ) showed highest germination percentage (51.40) followed by $\mathrm{T}_{4}$ (soaking in $2 \% \mathrm{H}_{2} \mathrm{O}_{2} 12 \mathrm{hrs}$ ). Although by soaking of seed in water the germination percentage was significantly lower $(40.14 \%$ and $38.34 \%)$ it can be resorted as an economical method of seed treatment for higher seedling production.

\section{Introduction}

The consumption and sale of wild edible fruits is a habit for scores of people residing in rural areas. Besides being the only source of nutritional supplement (Ruel et al., 2005; Balemie et al., 2006; Seal, 2011) for which they can afford and or access, wild edible fruits are also known to subsidize family income (Falconer, 1990; Seal et al., 2014; Chakravarty et al., 2016) of rural people. Lately, many wild edible fruits such as Anola, Rambutan, star fruits, Jackfruit, etc. have attained greater importance and there is large scale commercialization of the species. Systematic domestication and integration into mainstream agriculture have ensured sustainable harvest without affecting natural 
gene-pool. But for many, wild extraction is still followed and patterns and frequency of extraction has turned out to be unsustainable. The demand that began to emerge from urban areas has entailed huge economic prospects to collectors, contractors and retailers. Consequently the scale of extraction has escalated imposingsevere ecological threat to these species.

In Arunachal Pradesh, India Phoebe cooperiana U.N Kanjilal ex A. Dasfruits are highly demanded throughout the state. The tree is tall with compact crown attaining the height of approximately 30 metres and girth of 3 metres (Plate 1). It belongs to family Lauraceae and mainly distributed in tropical and subtropical rainforest of northeast India along the foothills of Eastern Himalayas upto an altitude $1600 \mathrm{~m}$ above msl. Popularly known as Mekhai in Assam, it has many local names in Arunachal Pradesh viz- Tapir/Tapil (Adi), Sangcher/Jishir (Nyishi), Samper (Apatani), Hisir (Galo), Educhi (Idu Mishmi) etc. The fruit is a berry which is $2-3.5 \mathrm{~cm}$ long, ellipsoid in shape, the immature fruit is greenish and black on ripe, inner part of the ripen fruit is oily, yellowish green with characteristic aroma and bitter taste (Plate 2).Fruits are available from September to December with an average cost ranging between Rs. 400/- to Rs. 500/- for 100 fruits in local markets. In addition, the tree is known for its quality timber with a compact crown and a clean bole of 15-18m length which is in high demand mainly by plywood industries. Owing to the desirable timber characters as well as edible nature of fruits, there is a huge demand for planting material of this species among the local community, forestry and private sectorsas well. Many farmers have started raising nurseries of the species and a single seedling can fetch a price of upto Rs.80/-. However, the species has not received the limelight it deserves from the scientific community. As per of now, there is no information on the basic morphological, nutritive characters of the fruits and neither on the ecology, reproductive biology and propagation methods of the species. In addition, the species is facing tremendous anthropogenic pressure from indiscriminate felling (Payum et al., 2013) and harvest of immature fruits. Consequently, population sizes have dwindled and natural regeneration scanty effecting population build up.

Presently there is a huge demand for planting material of the species but since the vegetative methods of propagation have been not been developed, the only method of regeneration is from seeds. But with very few matured seeds available for multiplication the challenge is to produce maximum plantable seedlings from available seeds. In this regard, standardizing pre-sowing treatment for maximum germination becomes necessary. The use of pre-sowing treatments for acceleration and enhancement of seed germination of some wild edible fruit trees include those of Ziziphus mauritiana and Macadamia integrifolia (Mbora, 2012), Elaeocarpus serratus (Dahanayakeet al., 2013), Terminalia chebula (Hossain et al., 2013), Manilkara hexandra (Bajaniya et al., 2018). Considering the overall lack of information on the species and the need to obtain information on the germination patterns of the species, we characterize fruit morphological parameters and investigate effects of pre-sowing treatment on seed germination of Phoebe cooperiana in the nursery condition.

\section{Materials and Methods}

Matured fruits of Phoebe cooperiana were collected during the month of November (2016) from Jia(Giya) under Roing Forest Range (28 03'32" N latitude; 95 46 $03^{\prime \prime}$ E longitude, at 169 m elevation), Lower Dibang Valley District, Arunachal Pradesh. 


\section{Characterization of fruit morphology}

Hundred fruits where used for characterizing fruit morphological parameters. Fruits weight was measured using electronic (digital) balance and expressed in gram $(\mathrm{g})$.The fruit length is the linear extended space from top point of the fruit to bottom point of the fruit apex. Fruit length and diameter was measured at the longest and widest point using Digital Calliper and expressed in centimetre $(\mathrm{cm})$. After pericarp was removed, the seed weight was taken using electronic Balance and expressed in gram (g). Seed length and diameter was measured at the longest and widest point using Digital Calliper and expressed in centimetre $(\mathrm{cm})$.

Pulp weight was estimated using formula:

$=$ (Fruit weight - Seed weight $) \mathrm{g}$

Pulp thickness was estimated using formula: $=($ Fruit diameter - Seed diameter $) \mathrm{cm}$

Pulp-fruit ratio was determined by formula: $=($ Pulp weight $/$ Fruit weight $)$

\section{Pre-sowing treatment}

Seeds were depulped manually and shade dried for one day for studying the effects of different pre-treatment on the germination parameters. A total of 300 seeds in three replicate with 100 seed per replicate were taken separately for each treatment for germination experiment in nursery condition. Each replicate of seeds were subjected to the following treatments: $\left(\mathrm{T}_{1}\right)$ - Control without any treatment; $\left(\mathrm{T}_{2}\right)$ - Soaking in water for 12 hours; $\left(\mathrm{T}_{3}\right)$ - Soaking in water for 24 hours; $\left(\mathrm{T}_{4}\right)$ - Soaking in $2 \%$ Hydrogen peroxide $\left(\mathrm{H}_{2} \mathrm{O}_{2}\right)$ for 12hours, $\left(\mathrm{T}_{5}\right)$ - Soaking in $0.05 \%$ Gibberellic acid (GA) for 12 hours, $\left(\mathrm{T}_{6}\right)$ Soaking in $0.1 \%$ Gibberellic acid (GA) for 12 hours, $\left(\mathrm{T}_{7}\right)$ - Soaking in $0.1 \%$ Potassium nitrate $\left(\mathrm{KNO}_{3}\right)$ for 12 hours, $\left(\mathrm{T}_{8}\right)$ - Soaking in $0.5 \%$ Potassium nitrate $\left(\mathrm{KNO}_{3}\right)$ for 12 hours.
Immediately after the pre-treatments, seeds were sown in prepared nursery beds and mulching was done. Watering was carried out regularly as per the requirement and observed daily for initiation and progress of germination until no more germination was observed. The first germination was started on $37^{\text {th }}$ day after sowing which was expressed as days to initial germination and was taken as visible signs of successful germination and data was recorded. The number of days on which the last seedling emerged was recorded and expressed as days to final germination. It took 70 days to complete the germination experiment from the date of sowing.

The various germination parameters such as germination percentage, peak value and germination value were calculated at the end of the experiments. Each treatment and the control were laid in Completely Randomized Design. Values of germination percentage were transformed (arcsine-square-root transformation) prior to analysis and were back transformed for tabular presentation. The obtained data was analysed using the analysis of variance procedure (ANOVA) variance following the model suggested by Panse and Sukhatme (1985). At the end of the germination period, the germination percentage, peak value, germination values were calculated using the following equations:

\section{Germination percentage}

The germination test was carried out in which four replicates of 100 seeds each were used (ISTA, 2003). The germination percentage was calculated using the formulae as:

Germination Percentage $=$

Number of seeds germinated

Total number of seeds used 


\section{Peak value}

Peak value was calculated as the maximum mean daily germination (MDG) reached at any time during the period of test (Czabator, 1962).

\section{Germination value}

Czabator's formula (1962), which quantifies germinative energy by combining speed and completeness of germination, was used for evaluation of the treatments.

Germination Value $=$ Final DGS $\mathrm{X}$ Peak value; where DGS is (Daily Germination Speed)

\section{Results and Discussion}

The average fruit weight for the 100 fruits was found to be $9.64 \mathrm{~g}$, fruit length $3.62 \mathrm{~cm}$ and fruit diameter was $2.42 \mathrm{~cm}$, while seed weight, seed weight and seed diameter was found to be was $3.10 \mathrm{~g}, 2.45 \mathrm{~cm}$ and $1.35 \mathrm{~cm}$, respectively (Table 1 ). The fruits are much larger than those of its close associate Phoebe goalparensis, an important timber species of the region (Jana and Singh, 2017) but slightly smaller than that of Elaeocarpus floribundus, the Indian olive (Bhowmick, 2017). Seed morphological parameters are also comparable to those of Elaeagnus latifolia, an underutilized fruit of the region (Patel et al., 2015) which showed mean seed weight of $3.19 \mathrm{~g}$, seed length $2.80 \mathrm{~cm}$ and seed diameter $1.29 \mathrm{~cm}$. One of the most important fruit parameters among edible fruits are the pulp content and pulp fruit ratio. These characters increase the marketability of the fruit. Average pulp weight, pulp thickness and pulp-fruit ratio was found to be $6.69 \mathrm{~g}$, $1.07 \mathrm{~cm}$ and 0.53 respectively (Table 1 ). These values are comparable to the pulp weight (3.67 to $10.33 \mathrm{~g}$ ) and pulp-fruit ratio (0.57 to 0.80) of Jamun (Singh et al., 2016; Rakesh,
2013), pulp thickness (5.64 to $6.72 \mathrm{~mm}$ ) and pulp-fruit ratio $(0.69$ to 0.74$)$ of $P$. nepaulensis (Rymbai et al., 2016).

Effect of different pre-sowing treatments on seed germination values of $P$. cooperianais presented in Table 2. The maximum germination percentage $(51.40 \%)$ was recorded in the treatment T5 (soaking in 0.05 $\%$ GA for 12 hours). This higher germination percent confirmed the role of Gibberellic acid as a stimulatory agent (Cetinbas and Koyuncu, 2006; Negi and Sharma, 2011). The highest germination value of T5 was followed by T4 $(44.49 \%)$ which was at par with T6 (44.45\%). The control (T1) seeds without any treatment showed lowest (31.88 \%) germination values, indicating to need for giving pre-sowing treatments to increase seedling production. Further, by imposing various seed treatments, the speed of germination has been significantly enhanced, which is an added advantage, given the recalcitrance nature of the seed where viability rapidly declines with time. In similar study, pericarp removed (depulped seeds) treated with soaking overnight in $0.05 \%$ gibberellic acid, soaking in water for overnight and soaking in $2 \%$ hydrogen peroxide for $12 \mathrm{hrs}$ before sowing resulted in earlier onset of enhanced germination in Phoebe goalparensis (Jana and Singh, 2017). The results reported in the present study were also supported by the findings of the many other authors. For example Murugesh (2011); Anand et al., (2012); Azad et al., (2012); Hossain (2014); Vijayalakshmi and Renganayaki (2017) have shown soaking of seeds in gibberellic acid and water has shown very good results.

There were highly significant $(p<0.05)$ differences among the treatments for peak value and germination value (Table 2). Treatments with higher germination percentages (T5, T4, and T6) also showed 
higher peak and germination values. This indicates a better measure of seed performance which is a prerequisite for the fast and uniform seed germination that, guarantees rapid and good seedling growth in the field (Shuaibu et al., 2015; Al-Absi, 2010). The rapid and complete germination of seeds is usually a desirable objective in the production of tree seedlings. Hence the findings indicate the need of seed pretreatment in Phoebe cooperiana due to scarcity of matured seeds available for regeneration.

Table.1 Characterization of fruit morphological parameters

\begin{tabular}{|r|l|c|}
\hline S.N. & \multicolumn{1}{|c|}{ Characters } & Values \\
\hline $\mathbf{1}$ & Fruit weight $(\mathrm{g})$ & $9.64 \pm 1.90$ \\
\hline $\mathbf{2}$ & Fruit length $(\mathrm{cm})$ & $3.62 \pm 0.37$ \\
\hline $\mathbf{3}$ & Fruit diameter $(\mathrm{cm})$ & $2.42 \pm 0.59$ \\
\hline $\mathbf{4}$ & Seed weight $(\mathrm{g})$ & $3.10 \pm 0.70$ \\
\hline $\mathbf{5}$ & Seed length $(\mathrm{cm})$ & $2.45 \pm 1.01$ \\
\hline $\mathbf{6}$ & Seed diameter $(\mathrm{cm})$ & $1.35 \pm 0.24$ \\
\hline $\mathbf{7}$ & Pulp weight $(\mathrm{g})$ & $6.69 \pm 1.10$ \\
\hline $\mathbf{8}$ & Pulp thickness $(\mathrm{cm})$ & $1.07 \pm 0.10$ \\
\hline $\mathbf{9}$ & Pulp-fruit ratio & $0.64 \pm 0.21$ \\
\hline
\end{tabular}

Table.2 Effect of pre-sowing treatment on germination parameters of seeds of $P$. cooperiana under eight treatments in nursery condition

\begin{tabular}{|c|c|c|c|}
\hline Treatments & Germination \% (Arcsine) & Peak Value & Germination Value \\
\hline T1 - Control & $28.17(31.88)$ & 0.40 & 0.16 \\
\hline $\mathrm{T} 2-\mathrm{H}_{2} \mathrm{O} 12 \mathrm{hrs}$ & $41.63(40.14)$ & 0.75 & 0.57 \\
\hline T3 - $\mathrm{H}_{2} \mathrm{O} 24 \mathrm{hrs}$ & $38.53(38.34)$ & 0.64 & 0.40 \\
\hline $\mathrm{T} 4-2 \% \quad \mathrm{H}_{2} \mathrm{O}_{2} \quad 12 \mathrm{hrs}$ & $49.14(44.49)$ & 0.82 & 0.68 \\
\hline T5 - $0.05 \%$ GA $12 \mathrm{hrs}$ & $61.02(51.40)$ & 1.02 & 1.01 \\
\hline T6 - $0.1 \%$ GA $12 \mathrm{hrs}$ & $49.08(44.45)$ & 0.78 & 0.61 \\
\hline $\mathrm{T} 7-0.5 \% \mathrm{KNO}_{3} 12 \mathrm{hrs}$ & $42.02(40.37)$ & 0.69 & 0.49 \\
\hline $\mathrm{T} 8-0.1 \% \mathrm{KNO}_{3} 12 \mathrm{hrs}$ & $30.32(33.28)$ & 0.50 & 0.26 \\
\hline Mean \pm SE & $42.49 \pm 2.26$ & $0.70 \pm 0.06$ & $0.52 \pm 0.08$ \\
\hline (Range) & $28.17-61.02$ & $0.40-1.02$ & $0.16-1.01$ \\
\hline M.S.S & $\mathbf{3 4 3 . 2 7}$ & 0.11 & 0.20 \\
\hline F- Test & $8.08 * *$ & $12.24 * *$ & $11.47 * *$ \\
\hline C.D. (5\%) & 6.84 & 0.17 & 0.24 \\
\hline C.V. (\%) & 9.66 & 13.65 & 26.24 \\
\hline
\end{tabular}

**Significant at the 0.05 p-level. 
Int.J.Curr.Microbiol.App.Sci (2019) 8(4): 2704-2711

Plate.1 Phoebe cooperiana tree

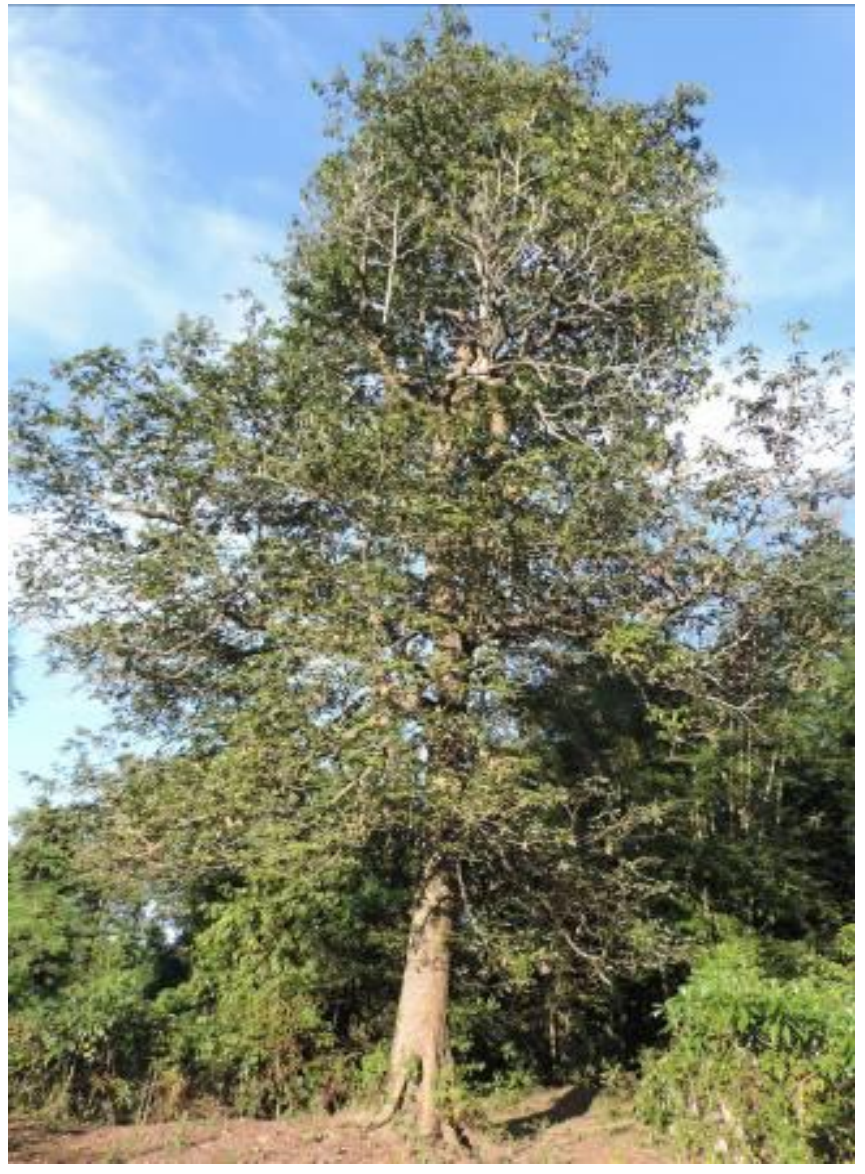

Plate.2 Fruits of Phoebe cooperiana

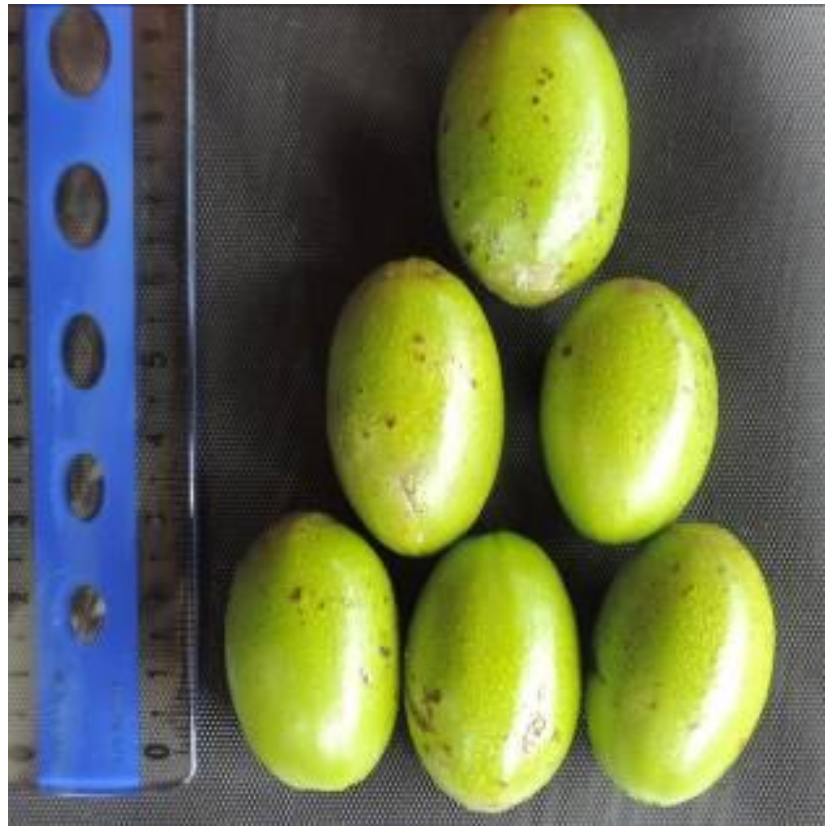


Although the present investigation reveals that the depulped seeds of Phoebe cooperianacan be treated with soaking for 12 hours in $0.05 \%$ gibberellic acid (T5) for best germination response, pre-sowing treatments of soaking in water for 12 hours $\left(\mathrm{T}_{2}\right)$ and soaking in water for 24 hours $\left(\mathrm{T}_{2}\right)$ of depulped seeds can give cost effective germination for large scale production of seedling with minimum cost, time, and labour. Therefore, considering availability of fund, resources and feasibility these presowing treatments could be adopted by the forest department, nursery owners, farmers, NGOs, and researchers for economic cultivation of this species.

\section{Acknowledgement}

The authors acknowledge the support received from the Central Agricultural University, Imphal under the project "Domestication of Phoebe cooperiana: an economically important wild edible fruit tree species of Arunachal Pradesh" (Grant No: CAU-DR/3-3(Horti.)/2010/Vol III/657 dtd $29^{\text {th }}$ June 2017).

\section{References}

Al-Absi, K.M. (2010).The effects of different presowing seed treatments on breaking the dormancy of Mahaleb cherries, (Prunus mahaleb L.) seeds. Seed Sci. Technol., 38: 332-340.

Anand, B., Devagiri, G. M., Maruti, G., Vasudev, H. S., and Khaple, A. K. (2012). Effects of pre-sowing seed treatments on germination and seedling growth performance of Melia dubia Cav: An important multipurpose tree. Int. j. life sci., 1(3): 59-63.

Azad, M.S., Manik, M.R., Hasan, M.S. and Matin, M.A. (2011). Effect of different pre-sowing treatments on seed germination percentage and growth performance of Acacia auriculiformis. J. of Forestry Res., 22(2): 183-188.

Bajaniya, V. G., Karetha, K. M., Parmar, L. S.,
Purohit, V. L. and Chotaliya, B. M. (2018). Influence of Pre-Soaking Treatment on Seedling Growth of Khirni (Manilkara hexandra Roxb) Seedling cv. Local. Int. J. Pure App. Biosci., 6 (1): 1668-1672

Balemie, K. and Kebebew, F. (2006). Ethnobotanical study of wild edible plants in Derashe and Kucha Districts, South Ethiopia. Journal of Ethnobiology and Ethnomedicine2:53.

Bhowmick, N. (2017). Fruiting characteristics of jalpai-the Indian olive (Elaeocarpus floribundus Blume.).J. Pharmacogn. Phytochem., 6(5): 608-609.

Cetinbas, M. and Koyuncu, F. (2006).Improving germination of Prunusavium L. seeds by gibberellic acid, potassium nitrate and thiourea.Hortsci.,(Prague) 33(3):119-123.

Chakravarty, S., Bhutia, K. D., Suresh, C. P., Shukla, G. and Pala, N. (2016). A review on diversity, conservation and nutrition of wild edible fruits. Journal of Applied and Natural Science 8 (4): 2346-2353.

Czabator, F.J. (1962). Germination value: an index combining speed and completeness of pine seed germination. For. Sci., 8(4): 386396.

Dahanayake, N., Alawathugoda, C. J. and Ranawake, A. L. (2013). Induce seed germination of Veralu (Elaeocarpus serratus L.). In: Proceedings of the Second International Symposium on Minor Fruits and Medicinal Plants for Better Lives (Eds.) Wathugala, D. L., Subasinghe, S., Athapaththu, N. S. B. N., Fonseka, K., Priyadharshani, N. D. N. (2nd ISMF \& MP), University of Ruhuna, Sri Lanka, 20 December 2013: pp.50-53

Falconer, J. (1990).Agroforestry and Household Food Security', in Agroforestry for Sustainable Production, Economic Implications, R T Prinsley (ed), Commonwealth Science Council, London.

Gupta, B.N. and Raturi, A.S. (1975). Tetrazolium staining of seeds for interpretation of viability of six Indian tree species. Ind. Forester. 101(11):659-673.

Hossain, M.A, Uddin, M.S., Abdu, A. and Shukor, N.A.A. (2014). Depulping of fruits and soaking the seeds enhances the seed germination and initial growth performance 
of Terminalia belerica Roxb. seedlings, Am. J. of Plant Sci., 5:714-725.

International Seed Testing Association (ISTA) (2003). Agricultural, Vegetable and Horticultural Species. In: Leist, N; Kramer, S; Jonitz, A. Basserdorf, (Ed.). ISTA Working Sheets on Tetrazolium Testing Vol. I. CH-Switzerland. p.200

Jana, L., \& Singh, B. (2017).Effect of Different Pre-sowing Treatments and Tetrazolium Test in Phoebe goalparensis Hutch. Under Eastern Himalayas, India. Int. J. Curr. Microbiol. App. Sci, 6(11): 3208-3214.

Mbora, A.M. (2012). Effect of pre-sowing treatment on germination of Macadamia integrifoloia and Ziziphus mauritiana fruits. Dissertation submitted in partial fulfilment of the award of the degree of Bachelor of Science in Dryland Natural Resource Management of Africa Nazarene University, p.41.

Murugesh (2011). Effect of seed pre-treatment on germination and seedling attributes of Grevillea robusta (Silver oak). My For., 47(1): 53-62.

Negi, P.S. and Sharma, S. (2011). Study on effect of gibberellic acid treatments on germination behaviour of Fraxinus xanthoxyloides seeds. Ind. J. For., 34(4): 409-413.

Panse, V.G. and Sukhatme, P.V. (1985). Statistical methods for agricultural workers. Fourth edition. The Indian Council of Agricultural Research, New Delhi, India. p. $1-381$.

Patel, S. (2015). Plant genus Elaeagnus: Underutilized lycopene and linoleic acid reserve with permaculture potential. Fruits, 70(4): 191-199.

Payum, T., Das, A.K., Ramashankar, R., Tamuly, C., and Hazarika, M. (2013). Ethnobotany and antioxidant determination of Phoebe cooperiana fruit-A highly utilized wild fruit in Arunachal Pradesh, India. Int. J. Pharm. Sci. Res., 4(8): 3196.

Rakesh, L. (2013). Provenance Variation in Seed and Seedling Traits of Jamun (Syzygium cumini, Skeels) in Uttar Kannada District (Doctoral dissertation, UAS, Dharwad).

Ruel, M.T., Minot, N. and Smith, L. (2005). Patterns and Determinants of Fruit and Vegetable Consumption in Sub-Saharan Africa: a Multicountry Comparison. Geneva, Switzerland: World Health Organization

Seal, T. (2011). Nutritional composition of wild edible fruits in Meghalaya state of India and their ethno-botanical importance. Res. J. Bot., 6(2): 58-57

Seal, T., Pillai, B. and Chaudhuri, K. (2014).Nutritional potential of wild edible fruits, traditionally used by the local people of Meghalaya state in India. Indian Journal of Natural Products and Resources, 5(4): 359-364.

Sharma, R.J., Gupta, R.C., Singh, S., Bansal, A. K., and Singh, I.P. (2016). Stability of anthocyanins and anthocyanidins-enriched extracts, and formulations of fruit pulp of Eugenia jambolana ('jamun'). Food chemistry, 190: 808-817.

Shuaibu, Y.M., Abdul, I., Abubakar, N. and Gambo, M. (2015). Effects of Different Methods of Breaking Seed Dormancy on the Germination of Flamboyant Seed (Delonix regia) in Bauchi State, Nigeria. The Int. J. Sci. Technol., 3(8): 194-197.

Singh, Y.S., Shira, V.D. and Swamy, G.S.K. (2016). Genetic variation for morphological and physicochemical traits in jamun (Syzygium cuminii Skeels). Asian J. Horti., 11(1): 163-167.

Vijayalakshmi, K.P. and Renganayaki, P.R. (2017). Effect of Pre-Sowing Treatment on germination of Red Sanders. Int. J. Curr. Microbiol. Appl. Sci., 6(4):168-173.

\section{How to cite this article:}

Narang Dolley, N. Lyngdoh, M. Bishwapati Devi and Hazarika, B.N. 2019. Characterization of Fruit Morphological Parameters and Effect of Pre-Sowing Treatment in Phoebe Cooperiana: An Economically Important Wild Edible Fruit of Arunachal Pradesh. Int.J.Curr.Microbiol.App.Sci. 8(04): 2704-2711. doi: https://doi.org/10.20546/ijcmas.2019.804.314 